\title{
Contribuições dos estudos marxianos para a Estética: reflexões sobre a sociedade contemporânea
}

Priscila de Souza Chisté Leite

Professora do Instituto Federal do Espírito Santo

\section{Resumo}

$\mathrm{O}$ artigo que segue apresenta alguns apontamentos de leitura sobre Estética e sua relação com a contemporaneidade. Por meio de pesquisa bibliográfica e imagens de obras de arte, discute aspectos da história da Estética e da sociedade atual. Apresenta reflexões marxianas sobre a sociedade capitalista e o processo de embrutecimento dos sentidos humanos para, a seguir, abordar as relações estabelecidas entre a Indústria Cultural e a sociedade de consumo com o intento de debater o processo de estetização da sociedade. Finaliza ao apontar a obra de arte e o efeito catártico proporcionado por ela como modos de estabelecer novas relações com a realidade e com as diferentes manifestações que buscam retratá-la.

Palavras-chave: Estética; Arte; Sociedade de Consumo.

\begin{abstract}
This article presents some critical aspects that result from readings on the history of Aesthetics as well as the critical observation of works of art, in order to bring forth relationships with issues of contemporary society. With the help of critics such as Marx, this article examines relationships between the so-called cultural industry and the society of consumption, with the purpose of suggesting a process of "aesthetization" of society. In closing, the text proposes that the well guided appreciation of works of art, and the resulting cathartic effect of that appreciation, are of great help to establish new relationships with the very many ways of expression of reality and, as a result, with reality itself.
\end{abstract}

Keywords: Aesthetics; Art; Consumption Society.

Filosofia e Educação [rfe] - volume 7, número 1 - Campinas, SP

Fevereiro-Maio de 2015 - ISSN 1984-9605 - p. 33-62 
Apresentação
$\begin{aligned} & \text { o presente texto pretendemos apresentar alguns apontamentos de } \\ & \text { leitura sobre Estética e sua relação com a contemporaneidade. } \\ & \text { Por meio de pesquisa bibliográfica, imagens de obras de arte e }\end{aligned}$ da mídia, discutimos aspectos da história da Estética e da sociedade atual. $\mathrm{Na}$ primeira parte, Apontamentos sobre a trajetória da estética, conceituamos algumas ideias de filósofos como Platão, Aristóteles, Baumgarten, Schiller, a partir das reflexões de Terry Eagleton, com o objetivo de situar conceitualmente as ideias estéticas de Marx. Assim, apresentamos reflexões de Marx sobre a sociedade capitalista e o processo de embrutecimento dos sentidos humanos, sob a luz de pensadores como Vázquez, nos trechos intitulados As ideias estéticas de Marx e A estética marxiana e a arte de massa. Abordamos as relações estabelecidas entre a Indústria Cultural e a sociedade de consumo, com o intento de debater o processo de Estetização da sociedade, no tópico Sociedade contemporânea, indústria cultural e estetização. Finalizamos o artigo, em diálogo com Lukács, com o capítulo A obra de arte e a catarse, apontando a obra de arte e o efeito catártico proporcionado por ela como modos de estabelecer novas relações com a realidade e com as diferentes manifestações espetaculares que buscam retratá-la. Esperamos, com a apresentação destas reflexões, que o leitor se aproxime do pensamento marxiano e de seus percussores e estabeleça novas relações com a realidade reificada.

\section{Apontamentos sobre a trajetória da Estética}

No dia a dia, em diferentes contextos, é muito comum ouvir falar sobre estética, como ocorre nos letreiros dos salões de beleza: Instituto de Estética; nos encartes promocionais: Estética Corporal, Estética Facial etc. Ambas as expressões se relacionam com a beleza física e abrangem um bom 
corte de cabelo, uma maquiagem "da moda" ou cuidados mais intensos com o corpo, como ginástica, massagens, tratamentos com cremes e cirurgias plásticas.

No campo da História da Arte, encontramos expressões como: estética renascentista, estética realista, estética modernista etc. Nesse sentido, a palavra "estética" designa um conjunto de características formais que a arte assume em determinado período.

Para a filosofia, estética relaciona-se com o estudo do belo e do sentimento que esse suscita nos homens. A estética aparece ligada à noção de beleza e por isso a arte tem lugar privilegiado nessa reflexão, pois, durante muito tempo, ela teve como função exprimir a beleza de modo sensível.

Etimologicamente, a palavra estética origina-se do grego, aisthesis, com o significado de "faculdade do sentir", "compreensão pelos sentidos", "percepção totalizante", reafirmando a ligação da estética com a arte. Assim, o objeto artístico é aquele que se oferece ao sentimento e à percepção. Segundo Santaella (1994), a raiz aisth, do verbo aisthanomai, quer dizer sentir com os sentidos, ou seja, com a rede de percepções físicas.

As questões relativas à estética, no Ocidente, tiveram sua origem no mundo grego a partir do pensamento de Platão (428-348). No diálogo de Filebo, Platão define aisthesis como uma excitação (pathos) da alma e do corpo, que leva ao conhecimento do mundo sensível. Já Aristóteles (1992) situa a aisthesis entre os cinco poderes ou faculdades da alma, caracterizando-a como aquela função encarregada de permitir ao ser humano formar, a partir dos objetos do mundo, uma imagem mental icônica desses objetos que refletisse, de modo transformado, o conhecimento abstrato. 
Para o Dicionário Básico de Filosofia de Japiassú e Marcondes (2008), estética é um dos ramos tradicionais da filosofia. O termo foi criado por Alexander Von Baumgarten, no século XVIII, para designar o estudo da sensação, "a ciência do belo", e referia-se à empiria do gosto subjetivo, àquilo que agrada aos sentidos, com fins à elaboração de uma ontologia do belo.

Terry Eagleton (1993) destaca que a estética nasceu como um discurso sobre o corpo. "Em sua formulação original, pelo filósofo alemão Alexander Baumgarten, o termo não se refere primeiramente à arte, mas com o grego aisthesis, a toda a região de percepção e sensação humanas, em contraste com o domínio mais rarefeito do pensamento conceitual" (EAGLETON, 1993, p. 17).

No ano de 1735, Baumgarten publicou Reflexões filosóficas sobre algumas questões pertinentes à poesia e, nesse artigo, pela primeira vez, empregou a palavra "estética", definindo-a como a ciência da percepção geral. Ele acreditava que o campo da lógica deveria ser ampliado por uma estética que incluiria a coisa cognoscível sensitivamente. Em sua obra posterior, Aisthetica (1750), essa ciência da percepção foi tomada como sinônimo de conhecimento pelos sentidos e partia da ideia de que existe uma estética natural, como uma capacidade inata que o ser humano possui para o pensamento belo, e também uma estética adquirida, que pode acontecer por meio do ensino ou da prática.

Nesse sentido, a estética surge do reconhecimento de que o mundo da percepção e da experiência não pode ser simplesmente derivado de leis universais abstratas, mas requer do seu discurso mais inferior uma lógica interna. A estética "[...] nasceu como uma mulher, subordinada ao homem, mas com suas próprias tarefas humildes e necessárias a cumprir" (EAGLETON, 1993, p.19).

Filosofia e Educação [rfe] - volume 7, número 1 - Campinas, SP Fevereiro-Maio de 2015 - ISSN 1984-9605 - p. 33-62 
O surgimento da estética relaciona-se também com a busca pela ascensão da burguesia em frente à aristocracia feudal, por uma ordem universal de sujeitos livres, iguais e autônomos. Por isso, era preciso pensar em um tipo inteiramente novo de sujeito, um sujeito que, assim como a obra de arte, “[...] descobre a lei na profundeza de sua própria identidade livre, e não em algum poder externo opressivo" (EAGLETON, 1993, p. 21).

Nesse contexto, coloca-se um novo desafio ideológico à ordem dominante. Isso produz novas dimensões do sentimento para além dos limites propostos pelo Absolutismo. Para que o poder fosse legitimado e conquistado pela burguesia, ocorreu um processo profundo de emancipação política em que a liberdade e a compaixão, a imaginação e o corpo foram ouvidos no interior do discurso de um racionalismo repressivo.

Portanto, é a partir de Baumgarten que essa área se tornou uma disciplina autônoma e culminou na Educação Estética, que teve início com os estudos de Schiller. Assim como Imanuel Kant ${ }^{1}$, Friedrich Schiller inserese no contexto Iluminista, marcado pela conscientização histórica, resultado do esforço de um pequeno grupo de literatos, escritores, críticos e filósofos. Vários episódios que ocorreram durante a Revolução Francesa, entre eles a

\footnotetext{
${ }^{1}$ Para Kant, o homem, em sua busca pelo conhecimento de mundo, precisa procurar também a harmonia com o mundo, pois, para haver conhecimento, é preciso que as nossas faculdades se ajustem à realidade material. É a contemplação desta forma pura de cognição, a harmonia com o mundo, que vem a ser estética. O filósofo acredita que existem duas fontes do conhecimento humano: a sensibilidade e o entendimento. Por meio da primeira, os objetos nos são dados; pela segunda, são pensados. Só pela conjugação desses dois elementos é possível a experiência do real. Portanto, para Kant, não somos capazes de conhecer as coisas como elas são em si, só conhecemos realmente o mundo dos fenômenos, da experiência, dos objetos enquanto se relacionam conosco, sujeitos, e não com a realidade em si, tal qual ela é, independentemente de qualquer relação com o conhecimento, pois o mundo dos fenômenos só existe na medida em que participamos dele. A obra de Arte para Kant é desinteressada, universalmente reconhecida por um sentimento ao mesmo tempo individual e coletivo. Contudo, as exigências kantianas ficam difíceis de serem cumpridas no século XXI, pois, neste momento, já não se pode mais conceber os juízos estéticos como puros e desinteressados; eles são, na maior parte das vezes, ditados por interesses mercadológicos. Na contemporaneidade, a arte cada vez mais servirá aos interesses múltiplos, como a busca desenfreada pelo lucro, a espetacularização e a diversão.
}

Filosofia e Educação [rfe] - volume 7, número 1 - Campinas, SP

Fevereiro-Maio de 2015 - ISSN 1984-9605 - p. 33-62 
execução do rei Luís XVI, deixaram Schiller decepcionado e o levaram a concluir que o Iluminismo não bastava para aperfeiçoar as relações políticas. Caberia somente à arte, inserida em um século indigno e bárbaro, o papel de purificar a humanidade.

Para Schiller, a arte é o impulso mais eficaz do ser humano, o meio mais efetivo de autorrealização humana e, por conseguinte, a Educação Estética deveria fomentar uma revolução total da maneira de sentir, tornando-se a base da construção de uma verdadeira liberdade humana.

Schiller (2002) tentou superar o seu mestre, Kant, no tratado $A$ Educação Estética do homem numa série de cartas. Nas cartas, ele diagnostica as questões centrais de sua época: a alienação, o isolamento, a divisão do trabalho, a consequente fragmentação do indivíduo, o Estado moderno e o desenvolvimento científico e cultural. Para ele, somente a formação da sensibilidade seria capaz de tirar os homens da condição da barbárie. Nesse sentido, considera o artista como o indivíduo capaz de se resguardar de "corrupções de sua época".

A ideia de Schiller era criar cidadãos que colaborassem para a liberdade política e civil. Para ele, a Educação Estética era a tarefa suprema do homem e, embora factível, não poderia ser inteiramente realizada, pois a humanidade jamais seria plenamente emancipada. Porém, acreditava que o indivíduo que se cultivasse e se enobrecesse moralmente não renunciaria à esperança de um dia vir a ser livre. Nesse sentido, educar e ser educado esteticamente significaria educar e ser educado pela soberania da imaginação.

De acordo com Schiller, a imaginação é a faculdade máxima na esfera estética, assim como o entendimento é a faculdade maior na esfera teórica e a razão na esfera prática. Este foi um dos maiores méritos de Schiller: tentar 
mostrar como essas faculdades remetem umas às outras no interior das diferentes esferas e como tais esferas se articulam num todo.

\section{As ideias estéticas de Marx}

No final do século XIX, a partir das ideias schillerianas, Marx critica o capitalismo industrial, as capacidades atrofiadas, os poderes dissociados e a totalidade da natureza humana arruinada. Ele inverteu Schiller ao apreender a liberdade humana como uma questão da realização dos sentidos e não como uma liberação deles. Porém, herda o ideal estético schilleriano que concebe o desenvolvimento integral das capacidades humanas como um fim em si mesmo (EAGLETON, 1993).

Contudo, não há, nos escritos de Marx, uma teoria sistemática da arte, embora tenha manifestado, durante toda sua vida intelectual, um grande interesse pela estética e pelas artes. Os vários e curtos trechos em que tratou dessas questões constituíram a base da estética marxiana. Tendo isso em vista, busca-se neste artigo entender as ideias de Marx sobre a estética, sabendo que, na tradição marxista, existem outros estudos que partem dos de Marx, mas que caminham por diferentes direções.

Para Marx, o objetivo da vida é a felicidade ou o bem-estar. A sua obra é uma investigação extensiva sobre as condições materiais necessárias para realizar esse objetivo. Ele nasceu em 1818 e foi um estudioso que exerceu grande influência sobre o pensamento filosófico, social e histórico da humanidade. A publicação tardia de vários de seus escritos promoveu a oportunidade também tardia do conhecimento da sua obra. Além disso, muitas de suas ideias foram obscurecidas pelas tentativas de adaptar o seu significado às circunstâncias políticas variadas.

Marx, alemão nascido de família de classe média, estudou na Universidade de Berlim, onde conheceu o pensamento hegeliano. Participou

Filosofia e Educação [rfe] - volume 7, número 1 - Campinas, SP

Fevereiro-Maio de 2015 - ISSN 1984-9605 - p. 33-62 
ativamente do movimento dos jovens hegelianos e produziu críticas severas ao Cristianismo. Foi trabalhar em um jornal liberal e escreveu incisivos artigos sobre as questões econômicas de sua época, o que implicou o fechamento do jornal pelo governo. Após o fechamento do jornal, Marx foi para Paris e, com um grupo de trabalhadores alemães, dirigiu uma revista que pretendia ser a ponte entre o nascente socialismo e as ideias dos hegelianos radicais alemães.

Durante os primeiros meses de permanência em Paris, começou a registrar suas ideias e novas concepções escrevendo os Manuscritos econômico-filosóficos de 1844, que permaneceram inéditos até 1930. Os Manuscritos esboçavam uma concepção humanista do comunismo, um comunismo que tinha como objetivo final a existência humana. Nessa ocasião, Marx, influenciado pela filosofia de Feuerbach, baseava-se no contraste entre a natureza alienada do trabalho no capitalismo e uma nova sociedade comunista na qual os seres humanos desenvolveriam livremente sua natureza em produção cooperativa.

Com os Manuscritos, Marx tenta decifrar a sociedade civil de ordem burguesa. Ele cria uma teoria da ordem burguesa. Ele empenhou-se em estudar a sociedade burguesa na perspectiva de subsidiar a luta operária. Para tanto, mergulha nas leituras sobre os economistas políticos, como Ricardo e Smith, e cria os Manuscritos, tidos como uma obra de transição, em que, pela primeira vez, Marx confronta as suas concepções teóricofilosóficas com a reflexão própria dos economistas políticos.

Os Manuscritos não foram redigidos para publicação, mas criados como material de estudo. Eles são um texto de transição em que Marx desenvolve um conjunto de determinações que serão recorrentes em sua obra, um texto radical, entendendo que ser radical implica tomar as coisas pela raiz.

Filosofia e Educação [rfe] - volume 7, número 1 - Campinas, SP Fevereiro-Maio de 2015 - ISSN 1984-9605 - p. 33-62 
Para Marx, a raiz do homem seria o próprio homem, pois o homem é uma constante tensão entre a sua genericidade humana, entre o seu ser genérico e a sua singularidade. O que é próprio do ser humano é existir como ser singular. Essa singularidade imediata que nos constitui é insuprimível; ela se transcende e se resolve na genericidade humana.

Marx considera que o homem é constituído de toda a sua referencialidade cultural, pois é o horizonte cultural que o transcende e do qual ele é portador. $\mathrm{O}$ homem só se expressa singular e genericamente na medida em que é um ser objetivo. É aquele que só se mantém enquanto tal na medida em que se objetiva. A objetivação é a condição da existência humana. Ela se dá por meio de formas pouco perenes como o gesto, o riso, o movimento, a fala cotidiana, mas também por meio de formas mais privilegiadas, como a Ciência, a Arte, a Literatura etc. Esse conjunto de objetivações, que é o acervo da humanidade, deve ser apropriado pelos indivíduos, precisa ser subjetivado pelos indivíduos. Porém, o objeto produzido só se torna uma objetivação da humanidade quando o homem não se perde mais nele, ou seja, o objeto só existe para o sujeito na medida em que o sujeito desenvolveu a faculdade necessária à apreensão do objeto.

O homem rico, para Marx, não é aquele que TEM; é aquele que É, pois o domínio da humanidade é o domínio do SER e não o domínio do TER. O homem rico é aquele que consegue subjetivar uma riqueza de objetivações. Para Marx, só é possível ser rico interiormente se se puder interiorizar a riqueza de objetivações da humanidade. Assim, a verdadeira riqueza é a elaboração das possibilidades criativas humanas, sem qualquer pressuposto além do desenvolvimento histórico anterior. Só o acesso às objetivações permite a subjetivação. Marx pensa no individuo socialmente constituído e, portanto, socialmente rico. Ninguém nasce rico ou pobre; é a sociedade que nos torna rico ou não. É o sistema de objetivações que faz emergir e 
desenvolver o ser social. A humanidade vem se desenvolvendo na medida em que desenvolve seus sistemas de objetivações. ${ }^{2}$ Sobre isso Marx pontua:

Vê-se como, em vez da riqueza e da miséria da economia política existe o homem rico e a necessidade humana rica. $\mathrm{O}$ homem rico é ao mesmo tempo aquele que tem necessidade de uma totalidade de manifestações humanas da vida. $\mathrm{O}$ homem para quem a sua própria realização existe como uma necessidade interior, como uma carência (MARX; ENGELS, 1986, p. 26).

Para Marx, a objetivação elementar que constitui o ser social é o trabalho. Ao conjunto dessas objetivações estaria preservado o conceito de práxis. Ele considera que o ser humano é prático e social. Esse caráter do homem é exemplificado paradigmaticamente pelo trabalho, objetivação privilegiada que garante a condição humana. O trabalho é a condição eterna do homem, integra a sua essência, ou seja, é o conjunto de atributos, qualidades que o ser humano, ao longo da sua trajetória na terra, conseguiu realizar.

O trabalho é a condição necessária para o aparecimento da arte, bem como da relação estética do homem com seus produtos. O trabalho é uma atividade consciente por meio do qual o homem transforma e humaniza a matéria. Foi por intermédio do trabalho que surgiu a criação artística. A arte nasce, no paleolítico superior, a partir do trabalho, "[...] recolhendo frutos da vitória do homem pré-histórico sobre a matéria, para assim elevar o humano - mediante esta nova atividade que hoje chamamos artística - a um outro nível” (VÁZQUEZ, 1968, p. 73). Nesse sentido, para que pudessem surgir

\footnotetext{
${ }^{2}$ Contudo, nem sempre as potencialidades criativas humanas são eficazes em termos de bem-estar. Isso se deve ao fato de que algumas capacidades humanas podem ser destrutivas, como a construção de campos de concentração que também foi uma realização dos poderes humanos (EAGLETON, 1993).
}

Filosofia e Educação [rfe] - volume 7, número 1 - Campinas, SP

Fevereiro-Maio de 2015 - ISSN 1984-9605 - p. 33-62 
os primeiros objetos artísticos, foi preciso que o homem afirmasse, pelo trabalho, um domínio cada vez maior sobre a matéria. O progresso ocorreu devido à fabricação de instrumentos que, ao se sofisticarem, possibilitaram a elevação do domínio do homem sobre a matéria, o que permitiu a ampliação das fronteiras da humanização e da natureza (VÁZQUEZ, 1968).Nesse momento, ao objeto é dado valor para além da sua utilidade. Leva-se em conta agora o objeto que materializa o potencial criador do homem.

A capacidade da subjetividade do homem é explicitada na relação estética do homem - ser social por essência - com a realidade. Nesse sentido, a obra de arte é um objeto no qual o sujeito se expressa, se exterioriza e reconhece a si mesmo. Se o homem só pode se realizar saindo de si mesmo, projetando-se para fora, isto é, objetivando-se; a arte cumpre uma alta função no processo de humanização do próprio homem.

Contudo, ter ou não contato como as objetivações da humanidade, por vezes, passa pela posição de classe. Esse contato, em larga medida, também é determinado pelo rendimento familiar. Como conhecer museus, ir ao teatro, assistir à apresentações musicais? Em algumas ocasiões é preciso ter condições financeiras para isso, o que muitas vezes não acontece com o trabalhador assalariado. Nesse sentido, o acesso aos espaços ligados à arte fica restrito aos mais favorecidos economicamente. Em outros momentos as pessoas não se sentem atraídas a realizarem tais programas culturais por desconhecimento ou por desinteresse.

Para Marx, no sistema capitalista a razão e o prazer estão em disputa. Uma das possibilidades de reconciliação é por meio do objeto artístico, que deve proferir modelos de reconciliação, sensualizar a razão e racionalizar o prazer, à maneira como vimos anteriormente, nas ideias de Schiller. Porém, nem sempre todos têm acesso a essas produções. Muitos nem sabem que existem espaços culturais destinados a apresentar as obras de arte para a

Filosofia e Educação [rfe] - volume 7, número 1 - Campinas, SP Fevereiro-Maio de 2015 - ISSN 1984-9605 - p. 33-62 
sociedade ou, quando sabem, não se sentem capazes de entender os trabalhos à mostra. A crescente instrumentalização da natureza e da humanidade, o processo do trabalho sob o domínio de uma lei abstrata e imposta, que se afasta de qualquer prazer corpóreo, são aspectos que podem explicar o distanciamento dos indivíduos das experiências sensíveis.

Não há, em Marx, a percepção sensorial pura, ou mesmo a pura intuição sensível, pois para ele, a evolução da percepção sensorial e do modo de intuir dos homens não se fez à margem do desenvolvimento das faculdades intelectuais especulativas e do raciocínio abstrato. Em suas pesquisas sobre essa questão, Konder (1967) enfatiza que o desenvolvimento da faculdade de pensar por meio de conceitos não acarreta a atrofia da faculdade de sentir, pois o homem se humaniza tanto no raciocínio como na sensibilidade. Ao desenvolver a sua capacidade de sentir as coisas, ele também enriquecerá sua reflexão a respeito delas. "O homem mais inteligente tende a ser, globalmente o mais sensível; e o mais bem dotado de sensibilidade tem maiores possibilidades para o desenvolvimento da sua inteligência" (KONDER, 1967, p. 29).

Para Marx, a percepção sensível deve ser a base de toda ciência. Só quando a ciência começa pela percepção sensível na sua forma dupla da consciência sensível e da necessidade dos sentidos, ela é verdadeiramente ciência. "Não foi, pois, apenas pelo pensamento, mas através de todos os sentidos que o homem se afirmou no mundo objetivo" (MARX; ENGELS, 1986, p. 24). Assim, a percepção sensorial é apresentada como uma faculdade que se desenvolve historicamente e cujo desenvolvimento é um aspecto substancial da autoconstrução do homem em geral. Complementa ainda que "[...] o homem premido pelas necessidades grosseiras e esmagado pelas preocupações imediatas é incapaz de apreciar mesmo o mais belo dos espetáculos" (MARX, 2004, p. 25).

Filosofia e Educação [rfe] - volume 7, número 1 - Campinas, SP Fevereiro-Maio de 2015 - ISSN 1984-9605 - p. 33-62 
Sobre o processo de humanização do homem, Marx aponta que, para confirmar a sua humanidade, "O homem se apropria da sua essência omnilateral [em todas as dimensões] de uma maneira omnilateral [de uma maneira compreensiva], portanto, como um homem total" (MARX, 2004, p.108).
Todas as relações humanas com o mundo - ver, ouvir, cheirar, saborear, sentir, pensar, contemplar, querer, agir, amar, em resumo, todos os órgãos da sua individualidade assim como aqueles que, na sua forma imediata, são comuns a todos - encontram-se na sua atitude objetiva ou na atitude para o objeto como uma adoção deste último. A adoção da realidade humana e sua atitude para com o objeto constituem a manifestação da realidade humana: a atividade e sofrimento humanos, para sofrer, encarados humanamente, representam a auto-satisfação do homem (MARX; ENGELS, 1986, p.77).

Assim, pela presença da cultura, tornamo-nos humanos. Nas palavras de Marx (2001, p. 143-144):

Só por meio da riqueza objetivamente desenvolvida do ser humano é que em parte se cultiva e em parte se cria a riqueza da sensibilidade subjetiva humana (o ouvido musical, o olho para a beleza das formas, em resumo, os sentidos capazes de satisfação humana e que se confirmam como capacidades humanas). Certamente, não são apenas os cinco sentidos, mas também os chamados sentidos espirituais [simbólicos], os sentidos práticos (vontade, amor, etc.), ou melhor, a sensibilidade humana e o caráter humano dos sentidos, que vêm à existência mediante a existência do seu objeto, por meio da 
característica humanizada. A formação dos cinco sentidos é a obra de toda a história mundial anterior.

Portanto, o fundamental é perceber que, na constituição do indivíduo, os sentidos e sentimentos são socialmente engendrados e se distanciam da sensibilidade animal constrangida pela necessidade imediata. Os sentidos se humanizam à medida que se produzem objetivações humanas (quando o homem coloca a sua marca no objeto) e estas são apropriadas (quando o homem incorpora as produções) em meio a relações sociais determinadas. "O olho tornou-se um olho humano, no momento em que o seu objeto se transformou em objeto humano, social, criado pelo homem para o homem" (MARX, 2001, p. 142). Com isso, enfatiza-se não apenas a necessidade do objeto (a natureza humanizada) na formação do sujeito, mas o próprio caráter histórico desse processo. Nesse sentido, considera-se a formação dos sentidos como trabalho de toda a história universal até a atualidade.

Para Marx, os sentidos não são apenas uma região isolável cujas leis são investigadas racionalmente, mas a própria forma de nossas relações práticas com a realidade. Para ele, o homem é um ser total. Contudo, o autor alerta que a propriedade privada nos tornou tão estúpidos e unilaterais, que um objeto só é nosso se o possuímos, ou seja, existe para nós como capital ou é utilizado por nós: imediatamente possuído, comido, bebido, usado no nosso corpo ou vivido.

Embora a propriedade privada considere todas essas encarnações de posse imediatas apenas como meios de subsistência, a vida que servem é a da propriedade privada, trabalho e capital. Portanto, verificou-se uma simples alienação de todos esses sentidos; e o sentido de ter ocupar o lugar de todos os sentidos físicos e espirituais.

Filosofia e Educação [rfe] - volume 7, número 1 - Campinas, SP

Fevereiro-Maio de 2015 - ISSN 1984-9605 - p. 33-62 
A existência humana tinha de ser reduzida a esta pobreza absoluta, para dar origem à sua riqueza intima... (MARX, 1986, p. 77).

A estética de Marx tem como base a filosofia da práxis, uma práxis que tende a transformar radicalmente a realidade humana a fim de instaurar uma sociedade na qual o homem possa explicitar criadoramente suas forças essenciais, frustradas, negadas, potencializadas ou despotencializadas. Esse marxismo se identifica como um verdadeiro humanismo, com a transformação radical do homem em todos os planos, o homem que seja o ser supremo para o homem. Nesse processo, o estético não pode ser alheio ao marxismo humanista, já que constitui uma dimensão essencial da existência humana.

Marx se interessou em definir o homem não só como produtor de objetos ou produtos materiais, mas também de obras de arte. Ele buscava, em seus estudos, o homem social que, nas condições econômicas e históricas da sociedade capitalista, se desfaz, se mutila ou nega a si próprio. "Esta mutilação do homem, ou perda do humano, se dá precisamente no trabalho, na produção material, isto é, na esfera na qual o homem deveria se afirmar como tal e que tornou possível a própria criação estética" (VÁZQUEZ, 1968, p. 52). Na sua busca pelo humano perdido, Marx encontra o estético como a esfera essencial. Ele volta-se para o estético a fim de esclarecer quanto o homem perdeu com a sociedade capitalista e vislumbrar quanto pode ganhar numa nova sociedade na qual dominem relações verdadeiramente humanas.

\section{A estética marxiana e a arte de massa}

Como foi apontado, Marx considera que, nas condições econômicas e históricas da sociedade capitalista, o homem perde a sua humanidade e nega 
a si próprio. Ao invés de afirmar-se no capitalismo, o homem aliena a sua essência. Em vez de humanizar-se, desumaniza-se.

$\mathrm{Na}$ sociedade capitalista, os homens não produzem para satisfazer diretamente suas necessidades pessoais ou comunitárias. Nesse processo, o homem perde sua dimensão especificamente humana - como atividade que revela a sua natureza criadora - para se reduzir a uma dimensão meramente econômica: produzir e consumir mercadorias.

O sistema capitalista se afirma na coisificação na medida em que propõe a coisificação da existência humana. Baseia-se em uma das formas mais repulsivas de manipulação dos indivíduos e das consciências: a máxima transformação do homem em coisa, em objeto. Vázquez intitula o homem que é manipulado como "homem-massa" - o homem ideal, do ponto de vista dos interesses desse capitalismo voraz,

[...] é o homem engendrado por suas próprias relações; isto é, o homem despersonalizado, desumanizado, oco por dentro, esvaziado de seu conteúdo, concreto e vivo, que pode se deixar modelar docilmente por qualquer manipulador de consciências; em suma, o homem-massa. Ora, qual é a arte ou pseudoarte que este homem-massa pode digerir ou consumir? Qual é a arte que o capitalismo tem interesse em patrocinar fundamentalmente, sobretudo numa sociedade industrial e altamente desenvolvida de um ponto de vista técnico, na qual se dão as condições para estender e aprofundar o processo de despersonalização ou massificação? Arte de massas (VÁZQUEZ, 1968, p. 276).

A arte de massas é aquela cujos produtos satisfazem as necessidades pseudoestéticas dos homens-massa, coisificados, que são, ao mesmo tempo, um produto característico da sociedade industrial capitalista.

Filosofia e Educação [rfe] - volume 7, número 1 - Campinas, SP

Fevereiro-Maio de 2015 - ISSN 1984-9605 - p. 33-62 
Seu consumo de massa acha-se assegurado pela existência de um público potencial, qualitativamente imenso, bem como pelas possibilidades de aceder a tais produtos artísticos em virtude dos poderosos meios de difusão (imprensa, rádio, cinema e televisão) que a técnica atual coloca à sua disposição. Estes produtos são, no terreno literário, as historietas e toda classe de novelas (fotonovelas, radionovelas e telenovelas), bem como a maior parte do romance policial; música, grande parte das canções chamadas modernas, românticas ou populares; e, no cinema, a maior parte da produção fílmica (VÁZQUEZ, 1968, p. 277).

A arte de massas é a caricatura da verdadeira arte. É uma pseudoarte produzida pela vontade da classe dominante para o gozo ou consumo das massas ou, mais exatamente, dos homens-massa. É uma arte que deixa o homem na superfície ou na margem das coisas e que se distingue, por sua vez, graças a uma linguagem astutamente fácil, que corresponde à sua falta de profundidade humana: "Uma linguagem que assegura uma inteligibilidade e comunicação tão mais extensas quanto mais superficial e vazio for seu conteúdo e quanto mais pobres, banais e débeis forem seus meios de expressão" (VÁZQUEZ, 1968, p. 277).

Qual seria a função da pseudoarte? Ela cumpre uma função ideológica bem definida: manter o homem-massa em sua condição de homem-massa, fazer com que se sinta tão massificado que não lhe seja permitido vislumbrar um mundo verdadeiramente humano e, com isso, a possibilidade de tomar consciência de sua alienação, bem como dos caminhos para destruí-la.

Para Vázquez, em uma sociedade na qual impera a lei fundamental do lucro, a produção não apenas produz produtos que satisfazem determinadas 
necessidades, mas também as próprias necessidades e, com elas, os consumidores. Sob os efeitos das técnicas de persuasão, da publicidade e de uma educação unilateral, tecnicista e coisificante, entre outras estratégias, os homens terminam por desejar o que não necessitam ou o que não corresponde às suas grandes necessidades humanas.

Para o autor, a preferência pela pseudoarte ocorre de modo induzido, fabricado, produzido de fora, no qual o produtor recorre a toda sorte de mentiras sobre as qualidades de seu produto, para assegurar o consumo mais vasto possível de suas mercadorias. Sobre a base de certas qualidades imaginárias, cria-se artificialmente o desejo de consumi-la, ainda que se trate de um produto que, na realidade, não satisfaz uma necessidade verdadeira de quem o adquire.

Vázquez aponta que, apesar de o público, em geral, nas condições próprias do consumo de massas, preferir quase sempre os produtos mais inconsistentes, do ponto de vista estético, isso não significa que não exista um setor que recuse tais produtos e busque outros mais elevados. "Mas a realidade é que, apesar dos esforços destas instituições e dos desejos de um setor mais exigente, o público outorga sua preferência aos subprodutos artísticos ou a obras de baixa ou duvidosa qualidade estética” (VÁZQUEZ, 1968, p. 287). É como se o gosto fosse adaptado para apreciar determinados produtos e falsas soluções que não discutem os problemas fundamentais dos seres humanos. Percebe-se, então, a grande necessidade de se pensar modos de resistir, problematizar e destruir essas estruturas alienantes.

\section{Sociedade contemporânea, Indústria Cultural e estetização}

Em consonância com as ideias de Marx e Vázquez, atualmente outras nomenclaturas e conceitos sobre o consumo das massas e para as massas foram elaborados, como o termo Sociedade de consumo.

Filosofia e Educação [rfe] - volume 7, número 1 - Campinas, SP

Fevereiro-Maio de 2015 - ISSN 1984-9605 - p. 33-62 
A Sociedade de consumo é consequência da expansão do capitalismo que assume hoje formas mais flexíveis de acumulação do capital. A flexibilidade é uma das características marcantes do modelo emergente de desenvolvimento e de organização do trabalho capitalista. A acumulação do capital flexível é também refletida nos processos de trabalho, mercados de trabalho, produtos e padrões de consumo. Uma de suas características é a integração e a organização de alguns países em blocos geoeconômicos como estratégias para proteger seus interesses contra os interesses de terceiros. Nesse sentido, o termo globalização expressa a ideia de um mundo mais integrado e interdependente não só em termos econômicos, mas também em questões sociais, culturais etc. (DELLA FONTE; LOUREIRO, 2003). “O conceito de aldeia global induz a pensar uma relação de continuidade e homogeneidade que não existe entre as nações. Nesse contexto, o termo globalização relaciona-se a um enfraquecimento do Estado-Nação e a universalização dos mercados e do capital" (DELLA FONTE; LOUREIRO, 2003, p. 32).

Por conseguinte, muitas vezes o desenvolvimento tecnológico é interpretado como sinônimo de libertação do ser humano em relação ao trabalho, em razão do aumento do tempo disponível para as atividades de lazer. Além da avançada tecnologia, a vida cotidiana passou a se constituir de informações abundantes que circulam em tão rápida velocidade que, muitas vezes, só é possível captar a sua imediatez, suas impressões superficiais.

Nesse sentido, o ritmo de produção de mercadorias é acelerado, os produtos tornam-se obsoletos, com o tempo de uso reduzido e provocam uma avalanche de modas fugazes. A produção acelerada corresponde a um consumo frenético mobilizado pelo trabalho publicitário de erotização das mercadorias e da realização hedonista.

Filosofia e Educação [rfe] - volume 7, número 1 - Campinas, SP

Fevereiro-Maio de 2015 - ISSN 1984-9605 - p. 33-62 
Sobre esse assunto, Freitas (2003, p. 51) coloca que "A sociedade contemporânea estabelece uma postura estética fundada no gozo narcisista de perceber todos os objetos consumidos como signos da inteireza do próprio ego". Segundo o autor, do mesmo modo que a personagem Narciso, da mitologia grega (Figura 1), apaixonou-se por sua própria imagem e acabou sucumbindo ao afogar-se na superfície da água que ele refletia, o indivíduo contemporâneo possui uma sede por conquistar uma expressão razoavelmente coesa daquilo que ele possa chamar de eu. "Significa a busca desse objeto tão acalentado que parece ser o único capaz de permanecer constante, apesar das flutuações de toda as desavenças políticas, correntes ideológicas, variação de humor do chefe, alterações do mercado de câmbio etc." (FREITAS, 2003, p.53).

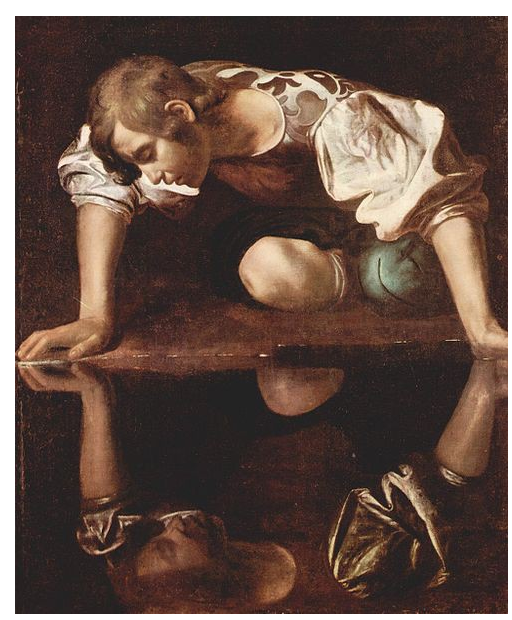

Figura 1

CARAVAGGIO, Michelangelo Merisi. Narciso, 1597. Óleo sobre tela, 110 x 92cm.

Freitas (2003) pontua que a sociedade de consumo atual parece introduzir uma caricatura bastante distorcida da característica da liberdade de nossas faculdades do juízo estético nos moldes kantianos. Todos os produtos que podemos comprar, músicas que podemos ouvir, filmes e 
propagandas a que podemos assistir produzem um ambiente em que proliferam uma dinâmica lúdica, despreocupada, que parece ser o oposto do trabalho maçante e repetitivo a que estamos sujeitos normalmente na vida cotidiana. A falsa liberdade de escolha dos locais de trabalho, a monotonia do trabalho que não possui criatividade e a infinidade de opções de objetos que nos circulam criam uma imagem falsa de liberdade a ser exercida virtualmente e sem limites.

Para Freitas (2003), a grande fantasia que move o indivíduo contemporâneo é a de que ele possui um ego suficientemente forte capaz de prolongar a sensação de prazer que ele busca em cada um dos objetos que poderia refletir sua imagem. $\mathrm{O}$ ego e todos os objetos de desejo funcionam como um sistema que confirma o merecimento de ter o desejado; é como se a possibilidade de comprar, de ouvir ou ver alguma coisa pudesse proporcionar esse vínculo. "Todos gostaríamos de nos sentir em casa no mundo, que funciona como uma enorme metáfora para o útero materno e para uma espécie de concepção espacial da nossa própria subjetividade" (FREITAS, 2003, p. 56). É a busca pelo TER que Marx tanto criticou.

Um exemplo que ajuda a entender as consequências do consumo exacerbado e a transformação disso em espetáculo é apresentado na série americana para a televisão chamada Acumuladores. Os programas são exibidos na televisão por assinatura, portanto não direcionados à classe popular. Discutem casos de extremo consumismo e o apego excessivo pelos objetos que impedem as pessoas de descartar qualquer coisa, por mais desnecessária ou absurda que possa parecer. Os apresentadores do programa visitam as casas de pessoas que sofrem de casos severos de acumulação extrema para abordar os aspectos psicológicos desse comportamento compulsivo e apresentam as aberrações nas vitrines televisivas.

Filosofia e Educação [rfe] - volume 7, número 1 - Campinas, SP Fevereiro-Maio de 2015 - ISSN 1984-9605 - p. 33-62 
O próprio site do programa apresenta um dos casos mais severos de acumulação extrema que veio à luz em março de 1947, quando a polícia de New York foi chamada para investigar a descoberta de um cadáver em um edifício de três andares no Harlem, que pertencia a dois irmãos idosos .

Quando os agentes entraram no imóvel, depararam-se com montanhas de lixo que chegavam até o teto, incluindo quatorze pianos, um automóvel e os restos de um feto de duas cabeças. Dentro de um sistema de túneis que usavam para andar entre os dejetos, estavam os corpos sem vida dos idosos: um foi esmagado pelo lixo, e o outro morreu de inanição.

Esse episódio nos leva a pensar que, do mesmo modo que o "Narciso" composto por lixo, de Vik Muniz (Figura 2), olha e contempla sua imagem como bela, os dois idosos, cobertos por lixo, contemplavam suas compras, consumiam compulsivamente até que, num dado momento, transformaramse naquilo em que suas compras haviam se transformado: lixo.

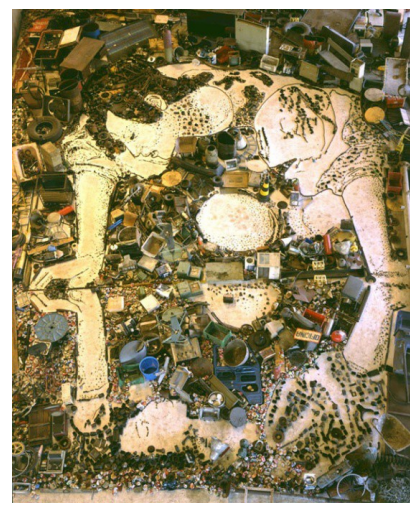

Figura 2

MUNIZ, Vik. Narciso depois de Caravaggio, 2005. Fotografia.

Esse caso é citado, desde a década de 1940, como exemplo do que o consumismo exacerbado pode causar. Aberrações como essas são alvo de interesse da televisão que, como redentora, agora pela via da Discovery, salvará aqueles que sucumbiram à sociedade de consumo: os acumuladores.

Filosofia e Educação [rfe] - volume 7, número 1 - Campinas, SP

Fevereiro-Maio de 2015 - ISSN 1984-9605 - p. 33-62 
Uma contradição, pois a mesma televisão que impulsiona o consumo insinua que consumir demais "faz mal à saúde".

As ideias de Freitas (2003) e de Della Fonte e Loureiro (2003) alertam que a imposição imagética dos veículos de comunicação de massa transforma a vida em algo para ser visto, um espetáculo no qual se prescinde do real e se advoga a sua representação, o seu simulacro. "Entre nós e o mundo estão os meios tecnológicos de comunicação/interação, ou seja, de simulação. Eles não nos informam sobre o mundo, simplesmente o refazem à sua maneira, hiper-realizam o mundo, transformando-o em espetáculo" (DELLA FONTE; LOUREIRO, 2003, p. 38).

A espetacularização e a banalização da vida também possuem um potencial de acomodação de conflitos e controle social. O mundo passa a se resumir naquilo que se vê nas imagens dos jornais, da televisão, das revistas. "O que não se vê é considerado inexistente. Nesse sentido o visível torna-se real e, portanto, é verdade" (DELLA FONTE; LOUREIRO, 2003, p. 39).

Della Fonte e Loureiro (2003) colocam que a equivalência entre o visível, o real e o verdadeiro adquire novos contornos à medida que se considera que a imagem também se transformou em uma mercadoria e se encontra, cada vez mais, submetida ao seu valor de troca. ${ }^{3}$ Como mercadoria, a imagem corresponde à visibilidade daquilo que se vende e se compra.

Sendo assim, é comum ouvir dizer que estamos não só na era da informação, mas também na era da civilização da imagem. Isso tem sido revelado pela crescente proliferação dos meios imagético-eletrônicos e dos sistemas computadorizados que vêm ocupando parte significativa das

\footnotetext{
${ }^{3}$ Valor de troca: é a expressão do trabalho abstrato contido na mercadoria, graças ao qual determinadas mercadorias podem ser equiparadas - vendidas ou compradas - no mercado. $\mathrm{O}$ valor não é determinado pelas propriedades naturais ou criadas das coisas, mas pelas relações sociais que elas plasmam (MARX apud VÁZQUEZ, 1968, p. 100).
}

Filosofia e Educação [rfe] - volume 7, número 1 - Campinas, SP

Fevereiro-Maio de 2015 - ISSN 1984-9605 - p. 33-62 
relações sociais na sociedade contemporânea (DELLA FONTE; LOUREIRO, 2003).

Como é possível observar, atualmente o cinema e a televisão representam as principais formas de mídia imagético-eletrônica, veículos de formação da cultura político-social no Ocidente e, provavelmente, também no Oriente, industrializado. Nesse ciclo alienante, o homem passa a não reconhecer mais a arte autêntica: "[...] ainda que a arte verdadeira se ofereça ao sujeito, este será incapaz de reconhecê-la por causa de sua impossibilidade de estabelecer uma relação propriamente humana - Estética - com ela" (VÁZQUEZ, 1968, p. 288).

Podemos concluir que a Indústria $\mathrm{Cultural}^{4}$ ou, nos moldes de Vázquez, a pseudoarte, é um dos modos incessantes que possibilitam a manutenção do sistema de valorização da mercadoria. Esse processo de valorização é chamado de estetização: uma espécie de embelezamento superficial da mercadoria cujo conteúdo abriga (ou esconde) apenas o valor de troca. É como se a política, a ética e a religião pudessem ser diluídas na estética, supervalorizando-a em detrimento das outras dimensões. "A mercadoria se transforma, se embeleza - seja pela introdução de novas tecnologias, seja pelo relativismo de modelos passados, pelo pastiche ou pelo ecletismo que mistura elementos de diferentes épocas - inserindo novos meios de extração de mais-valia" (TROJAN, 2007, p. 14).

\footnotetext{
${ }^{4}$ A Indústria Cultural, termo cunhado por Adorno e Horkheimer, surgiu da necessidade desses autores de abandonar o termo cultura de massas. Assim, utilizaram Indústria Cultural para descaracterizar a concepção de que a cultura que se produz, aparentemente de forma espontânea no cotidiano das massas, seja uma forma atualizada da Arte popular. Para eles, Indústria Cultural é a fábrica de realidade e fantasia; e a mídia é o espelho que reflete, orienta do que se deve gostar, desejar, o que se deve sentir, pensar e fazer. A Indústria Cultural expressa a dinâmica da mercantilização da cultura na sociedade capitalista mais avançada, na qual a indústria e a racionalidade da produção modificam o processo de criação cultural e conferem uma homogeneidade de padrão que perpassa diferentes veículos culturais (DELLA FONTE; LOUREIRO, 2003).
}

Filosofia e Educação [rfe] - volume 7, número 1 - Campinas, SP

Fevereiro-Maio de 2015 - ISSN 1984-9605 - p. 33-62 
Nesse contexto, o conhecimento também se torna mercadoria e junto com ele os valores estéticos, éticos e políticos que constituem a imagem. Nessa perspectiva, a função social da educação é “[...] adequar o modo de conhecer, fazer, ser e conviver das pessoas às novas formas de organização e de produção econômica, às representações ideológicas que correspondem ao atual estágio de desenvolvimento do capitalismo e às relações que lhe correspondem" (TROJAN, 2007, p. 14).

Longe da estética proposta por Marx, na perspectiva de refletir sobre um mundo essencialmente humano, a estetização do real - próprio da estética da mercadoria cujo conteúdo é a própria forma - se constitui como imperativo da sociedade contemporânea. A estetização do real atravessou todos os âmbitos da experiência subjetiva. Como aponta Farina (2008), a indústria da felicidade hoje não comercializa apenas medicamentos antidepressivos, ou produtos como pacotes de viagens que incluem turismo e cirurgia estética, ou ainda mercadorias como pets excêntricas - mas a própria experiência estética. "Já não se adquire um automóvel último tipo, mas um estilo de vida. O que está em jogo é como as relações com esse comércio afetam as relações conosco próprios e entre nós" (FARINA, 2008, p. 3).

Nesse sentido, as imagens e os discursos que compõem nosso universo estético têm o poder de orientar ética e politicamente nossas práticas, pois nos dão referências sobre o que vemos, pensamos e fazemos. A estetização da sociedade contribui para justificar a ordem social e o processo de reestruturação produtiva. Substitui a ética pela estética no âmbito da política e causa grande impacto na sociedade.

\section{Obra de arte e catarse}

Em contraponto à situação descrita está a obra de arte. $\mathrm{O}$ encontro com essa

Filosofia e Educação [rfe] - volume 7, número 1 - Campinas, SP

Fevereiro-Maio de 2015 - ISSN 1984-9605 - p. 33-62 
produção humana, ou seja, a experiência estética, pode contribuir para o processo reflexivo originado pela relação do sujeito com a obra de arte. Esse processo é fundamental para colaborar com a transformação das estruturas alienantes, proporcionando uma nova atitude diante dos acontecimentos cotidianos. Portanto, a Arte, tende a possibilitar ao homem transcender à fragmentação produzida pelo fetichismo da sociedade capitalista. Ela produz uma elevação, uma suspensão da cotidianidade, uma elevação da subjetividade do plano meramente singular para o campo mediador da particularidade que a separa inicialmente do cotidiano para, no final, fazer a operação de retorno à vida de modo enriquecido.

A relação entre obra de arte e receptor implica, necessariamente, uma relação social, uma troca entre sujeitos, um diálogo tanto com o autor da obra quanto com as vozes sociais que ecoam na obra. Permite desencadear um processo reflexivo fundamental na construção social do indivíduo, provoca reflexões transformadoras sobre estruturas alienantes, manipuladoras e obliteradoras da realidade, proporciona uma nova atitude diante dos eventos cotidianos. Essa reflexão é fundamental na formação do indivíduo, pois como foi dito, nossa sociedade está calcada na espetacularidade dos acontecimentos, em que o espetáculo da realidade, por vezes, substitui a própria realidade. Nesse contexto, um olhar aguçado, aliado a um senso crítico apurado, colabora para o estabelecimento de novas relações com essa realidade e com as diferentes manifestações espetaculares que buscam retratá-la.

As reflexões suscitadas pela obra de arte fazem parte de um contínuo processo de formação e de transformação que colabora com a construção das relações que envolvem o processo de apreender a Arte e que, portanto, integra uma proposta de nos desenvolvermos à altura das máximas possibilidades existentes no gênero humano.

Filosofia e Educação [rfe] - volume 7, número 1 - Campinas, SP

Fevereiro-Maio de 2015 - ISSN 1984-9605 - p. 33-62 
O encontro com a obra de arte torna possível a cada indivíduo reconhecer sua própria essência, sua história no processo de desenvolvimento do ser humano. Como aponta Lukács, ocorre um processo que possibilita aos homens "[...] a síntese ontológico-social de sua singularidade, convertida em individualidade, com o gênero humano, convertido neles, por sua vez, em algo consciente de si" (LUKÁCS, apud FOERSTE, 2004, p. 33).

Lukács (1966) nos esclarece que o poder orientador e evocador da Arte penetra na vida do receptor, subjuga seu modo habitual de contemplar o mundo e chama a atenção para o mundo cheio de conteúdos novos ou visto de modos novos. Faz com que o indivíduo receba esse mundo com sentidos e pensamentos rejuvenescidos, renovados (LUKÁCS, 1966). Esse poder da Arte é o que leva o homem à catarse, compreendida pelo filósofo como "[...] efeito que desencadeia o choque entre o mundo objetivo esteticamente refletido com a mera subjetividade cotidiana" (LUKÁCS,1966, p. 517, tradução nossa). É nesse processo catártico que (ao menos em tese) é possível ocorrer a transformação do homem inteiro (imerso na cotidianidade) em homem inteiramente receptível à Arte, que amplia e enriquece conteúdos e formas, efetivos e potenciais da sua psique. Traz novos conteúdos que aumentam seu tesouro vivencial, desenvolve sua capacidade receptiva e sua capacidade de reconhecer e gozar novas formas objetivas, novas relações, etc.

Ao se comover pela obra de arte, o receptor desencadeia um sentimento negativo, um pesar por não ter percebido nunca, na realidade, na própria vida, o que tão "naturalmente" se oferece na conformação artística. Assim, “[...] nessa comoção contém uma anterior contemplação enfeitiçadora do mundo, a sua destruição pela sua própria imagem desenfeitiçada na obra de arte e a autocrítica da subjetividade" (LUKÁCS, 
1966, p. 507, tradução nossa). Essa relação ética, submetida ao efeito catártico, é "[...] uma sacudida tal da subjetividade do receptor que as suas paixões vitalmente ativas cobrem novos conteúdos, uma nova direção e, assim, purificadas, se transformem em embasamento anímico de ‘disposições virtuosas"” (LUKÁCS, 1966, p. 508, tradução nossa).

A Arte, tende a possibilitar ao homem transcender à fragmentação produzida pelo fetichismo da sociedade capitalista. Ela produz uma elevação, uma suspensão da cotidianidade, uma elevação da subjetividade do plano meramente singular para o campo mediador da particularidade que a separa inicialmente do cotidiano para, no final, fazer a operação de retorno à vida, de olhos mais abertos. Nesse sentido, cada catarse estética é um reflexo concentrado e consciente produzido de comoções contidas na vida. O processo catártico desencadeado no receptor reflete os traços mais essenciais dessas constelações vitais. A catarse se traduz num processo de encontro entre sujeitos (obra e receptor), de quebra de uma realidade alienante, proporcionando trocas de saberes e afetividades. Dentro desse processo de interação social, a transformação do indivíduo não ocorre instantaneamente, ela é gradual e variável, pois, acontece por meio de encontros e de convívio com a obra de arte.

\section{Referências}

ARISTÓTELES. Poética. Tradução de Eudoro de Souza. Lisboa: Imprensa Nacional/Casa da Moeda, 1992.

DELLA FONTE, Sandra Soares; LOUREIRO, Robson. Induistria cultural e educação em “tempos pós-modernos”. São Paulo: Papirus, 2003.

EAGLETON, Terry. A ideologia da estética. Rio de Janeiro: Jorge Zahar Editor, 1993. 
FARINA, Cynthia. Arte e formação: uma cartografia da experiência estética atual. In: Reunião Anual da Associação Nacional de Pós-graduação e Pesquisa em Educação, 2008, Caxambu. Anais Eletrônicos. Disponível em: <http://www.anped.org.br/reunioes/31 ra/1trabalho/GE01-4014--Int.pdf>. Acesso em: 10 jun. 2012.

FOERSTE, Gerda Margit Schütz. Leitura de imagens: um desafio à educação contemporânea. Vitória: EDUFES, 2004.

FREITAS, Verlaine. A estética narcisista da sociedade de consumo. Revista Educação e Filosofia, Universidade Federal de Uberlândia, v. 17, n. 34, jul./dez. 2003. Faculdade de Educação, Departamento de Filosofia e Programa de PósGraduação em Educação.

JAPIASSU, Hilton; MARCONDES, Danilo. Dicionário básico de filosofia. Rio de Janeiro: Jorge Zahar, 2008.

KESTLER, Izabela Maria Furtado. Friedrich Schiller e a fundação do cânone da modernidade. Forum Deustch - Revista Brasileira de Estudos Germanísticos, v. 10, p. 88-125, 2006.

KONDER, Leandro. Os marxistas e a arte: breve estudo histórico-crítico de algumas tendências da estética marxista. Rio de Janeiro: Editora Civilização Brasileira, 1967.

- O futuro da filosofia da práxis: o pensamento de Marx no século XXI.

Rio de Janeiro: Paz e Terra, 1992.

LUKÁCS, Georg. Estética 1-La peculiaridad de lo estético. Barcelona (México): Ediciones Grijaldo, 1966.

MARX, Karl. Manuscritos econômico-filosóficos. Tradução de Jesus Ranieri. São Paulo: Boitempo, 2004. Manuscritos econômico-filosóficos. Tradução de Jesus Ranieri. São Paulo: Editora Martin Claret Ltda, 2001.

MARX, Karl; ENGELS, Friedrich. Sobre literatura e arte. São Paulo: Global editora, 1986.

Filosofia e Educação [rfe] - volume 7, número 1 - Campinas, SP

Fevereiro-Maio de 2015 - ISSN 1984-9605 - p. 33-62 
- A ideologia alemã: crítica da mais recente filosofia alemã em seus representantes Feuerbach, B. Bauer e Stirner, e do socialismo alemão em seus diferentes profetas (1845-1846). São Paulo: Boitempo, 2007.

SANTAELLA, Lúcia. Estética de Platão a Peirce. São Paulo: Experimento, 1994.

SCHILLER, Friedrich. Educação estética do homem. São Paulo: Iluminuras, 2002.

TROJAN, Rozeli Meri. (Pós)-modernismo, trabalho e educação. In: Reunião

Anual da Associação Nacional de Pós-graduação e Pesquisa em Educação, 2007, Caxambu. Anais Eletrônicos. Disponível em: <http://www.anped.org.br/ reunioes/30ra/grupo_estudos/GE01-3018--Int.pdf>. Acesso em: 10 jun. 2012.

VÁZQUEZ, Adolfo Sánchez. As ideias estéticas de Marx. Rio de Janeiro: Paz e Terra, 1968. 